Article

\title{
Preparation and Characterization of Microencapsulated Phase Change Materials for Use in Building Applications
}

\author{
Jessica Giro-Paloma ${ }^{1}$, Refat Al-Shannaq ${ }^{2}$, Ana Inés Fernández ${ }^{1}$ and Mohammed M. Farid ${ }^{2, *}$ \\ Received: 6 November 2015; Accepted: 21 December 2015; Published: 26 December 2015 \\ Academic Editor: Luisa F. Cabeza \\ 1 Department of Materials Science and Metallurgical Engineering, Faculty of Chemistry, \\ Universitat de Barcelona, C/Martí i Franquès, Barcelona 1. 08028, Spain; jessicagiro@ub.edu (J.G.-P.); \\ ana_inesfernandez@ub.edu (A.I.F.) \\ 2 Department of Chemical and Materials Engineering, University of Auckland, Private Bag 92019, \\ 20 Symonds Street, Auckland 1142, New Zealand; rals187@aucklanduni.ac.nz \\ * Correspondence: m.farid@auckland.ac.nz; Tel.: +64-21-812-678
}

\begin{abstract}
A method for preparing and characterizing microencapsulated phase change materials (MPCM) was developed. A comparison with a commercial MPCM is also presented. Both MPCM contained paraffin wax as PCM with acrylic shell. The melting temperature of the PCM was around $21^{\circ} \mathrm{C}$, suitable for building applications. The M-2 (our laboratory made sample) and Micronal ${ }^{\circledR}$ DS 5008 X (BASF) samples were characterized using SEM, DSC, nano-indentation technique, and Gas Chromatography/Mass spectrometry (GC-MS). Both samples presented a $6 \mu \mathrm{m}$ average size and a spherical shape. Thermal energy storage (TES) capacities were $111.73 \mathrm{~J} \cdot \mathrm{g}^{-1}$ and $99.3 \mathrm{~J} \cdot \mathrm{g}^{-1}$ for M-2 and Micronal ${ }^{\circledR}$ DS 5008 X, respectively. Mechanical characterization of the samples was performed by nano-indentation technique in order to determine the elastic modulus $(E)$, load at maximum displacement $\left(P_{m}\right)$, and displacement at maximum load $\left(h_{m}\right)$, concluding that M-2 presented slightly better mechanical properties. Finally, an important parameter for considering use in buildings is the release of volatile organic compounds (VOC's). This characteristic was studied at $65^{\circ} \mathrm{C}$ by CG-MS. Both samples showed VOC's emission after $10 \mathrm{~min}$ of heating, however peaks intensity of VOC's generated from M-2 microcapsules showed a lower concentration than Micronal ${ }^{\circledR}$ DS 5008 X.
\end{abstract}

Keywords: microencapsulated phase change material; volatile organic compounds; nano-indentation; differential scanning calorimetry

\section{Introduction}

Thermal energy storage (TES) using phase change materials (PCM) has shown a significant increased attention because of its important role on energy conservation in buildings [1-4]. PCM can be used for TES in buildings [5] either in passive [6] or active systems [7-9], aiming to improve the thermal managements of these buildings. In most of the applications, PCM were used either in macroencapsulated [10,11] or microencapsulated [12-14] forms, for heating [15], air-conditioning [16], ventilation [17], refrigeration [18], and heat exchangers [19] for building applications [3,20-22].

Microencapsulation process is defined as a technique in which small particles or droplet are enclosed by a coating, or surrounded in a homogeneous or heterogeneous matrix, to provide microcapsules $(1-100 \mu \mathrm{m})$. For this reason, the microencapsulated phase change materials (MPCM) are composed of PCM as a core and a polymer as a shell used to preserve the spherical shape of the microcapsule and avoid PCM leakage during phase change [12,23]. The use of MPCM in buildings [24-27] can decrease daily inner temperature fluctuation during summer and winter [28]. 
The suitability of the shell used in encapsulating specific core PCM is a key issue in order to ensure proper thermal performance of the MPCM $[13,29,30]$, especially in preventing PCM leakage when it melts. Additionally, MPCM can be easily incorporated in gypsum board [31,32], plaster [33], and concrete [34] used in buildings.

The complete characterization of materials used in indoor environments like MPCM is very important. The exposure to chemical compounds could cause health problems (nausea; dry skin; eye, nose or throat irritations; headache; irritated eyes; dizziness; difficulty in concentrating; psychological stress) in indoor environments [35-38] (buildings, for example [39-47]) or outdoor environments [48]. These problems are known as sick building syndrome (SBS) [37,49-51]. Volatile organic compounds (VOC's) are defined as any organic compound having an initial boiling point less than or equal to $250{ }^{\circ} \mathrm{C}$ at a standard pressure of $101.3 \mathrm{kPa}$ [52]. VOC's are one of the most important groups of trace contaminants in the atmosphere known for its photochemical, toxic, and radioactive effects. For this reason there are some studies, guides $[53,54]$, and database $[55,56]$ related to this effect. Formaldehyde [39,46,57] and benzene [58] are some of the most studied pollutants since they are classified in Group 1 of human carcinogens by the IARC 2004 (International Agency for Research on Cancer). Other chemicals known for their health hazard are acetaldehyde, toluene, and xylenes [59]. By this way, VOC's evaluation of the outdoor and indoor air quality has been evaluated [28-31] in materials for buildings like gypsum base PCM composites [60] but it has not been reported for building materials containing MPCM. For this reason, the characterization of VOC's of MPCM is an important contribution to the state of the art of the environmental properties of MPCM.

The main purpose of this research is to develop, prepare, characterize, study, and compare thermal and mechanical properties of microcapsules containing organic PCM in order to assess their suitability for use in buildings and other applications. The samples under study are commercial MPCM (Micronal ${ }^{\circledR}$ DS 5008 manufactured by BASF, Berlin, Germany) and a laboratory prepared one by us (M-2). Micronal ${ }^{\circledR}$ DS 5008 sample has been used extensively in concrete, gypsum, lime plaster, and gypsum plaster, without being fully characterized for fire hazards. The comparison includes fire retardancy and gas emission released to environment from upon fire. It is important to establish a characterization methodology, which will include both volatile emission measurements and nano-indentation technique to measure the shell mechanical strength of the microcapsules. This is very important issue in the selection of PCM products, especially for use in building application. PCM microcapsules should have high phase change enthalpy, uniform spherical shape, acceptable thermal stability, good mechanical properties, and low release of hazardous gases in the form of volatile organic compounds.

\section{Materials and Methods}

\subsection{Materials}

The chemical preparation of microcapsules required the following reagents:

- Shell: Methyl methacrylate (MMA) $(99 \%$, contains $\leqslant 30$ ppm monomethyl ether hydroquinone (MEHQ) as inhibitor, Sigma Aldrich, Auckland, New Zealand) and pentaerythritol tetraacrylate (PETRA) (contains 350 ppm (MEHQ), Sigma Aldrich, Auckland, New Zealand) were used as a monomer and cross-linking agent respectively in order to obtain proper shells for MPCM.

- Free radical thermal initiator: Luperox ${ }^{\circledR}$ A75, Benzoyl peroxide (BPO) $(75 \%$, contains $25 \%$ water, Sigma Aldrich, Auckland, New Zealand) was used as free radical thermal initiator.

- Surfactants: Polyvinyl alcohol (PVA) $\left(\mathrm{M}_{\mathrm{w}}\right.$ 85,000-124,000, Sigma Aldrich, Auckland, New Zealand) and sodium dodecyl sulfate (SDS) (BioXtra, 99\%, Sigma Aldrich, Auckland, New Zealand) were used as a non-ionic and ionic surfactant, respectively.

- $\quad$ PCM: a commercial paraffinic PCM, Rubitherm ${ }^{\circledR} \mathrm{RT} 21\left(\mathrm{~T}_{\mathrm{m}}=21^{\circ} \mathrm{C}, \Delta \mathrm{H}_{\mathrm{m}}=135 \mathrm{~J} \cdot \mathrm{g}^{-1}\right.$, Rubitherm ${ }^{\circledR}$ Technologies GmbH, Berlin, Germany) was used. 
The bulk density of M-2 microcapsules is $0.496 \mathrm{~g} \cdot \mathrm{mL}^{-1}$. The commercial MPCM, Micronal ${ }^{\circledR}$ DS $5008 \times\left(\mathrm{BASF}^{\circledR}\right)$, was also selected for characterization and was compared with the microcapsules produced in this work. This sample is also composed by an acrylate shell and organic PCM in the core [13], and its bulk density is $0.445 \mathrm{~g} \cdot \mathrm{mL}^{-1}$.

\subsection{Synthesis of PCMs Microcapsules}

\subsubsection{Emulsification}

A standard procedure was used as reported elsewhere [61]. Wherein, an aqueous solution of surface-active agent (called aqueous phase) and a mixture of MMA, PETRA, BPO, and PCM (called organic phase) were prepared separately. The organic phase was added to the aqueous phase and emulsified mechanically using a high shear mixer (Silverson L5M-A laboratory Mixer, Silverson LTD, East Longmeadow, MA, USA). A stirring rate of $3000 \mathrm{rpm}$ for $5 \mathrm{~min}$ was chosen to achieve the required emulsification.

\subsubsection{Polymerization}

The produced emulsion was transferred to a 2-L four-neck glass reactor (LR-2.ST laboratory reactor-IKA-Werke, Gmbh@Co.KG, Staufen, Germany) consisting of EUROSTAR 200 control P4, Anchor stirrer LR 2000.1, HBR 4 digital heating bath. The agitation speed was set at approximately $300 \mathrm{rpm}$, and the temperature of the water bath was maintained at $70{ }^{\circ} \mathrm{C}$ for $2 \mathrm{~h}$, and then adjusted to $85^{\circ} \mathrm{C}$ for another $4 \mathrm{~h}$. The water bath was then switched off and allowed to cool down naturally to room temperature. After cooling, the suspension of PCM microcapsules was transferred to a clean glass beaker and washed three times with distilled water to remove the unreacted monomers and the non-encapsulated PCM. The separated microcapsules were spread on a tray and placed in an oven at $50{ }^{\circ} \mathrm{C}$ for $48 \mathrm{~h}$ for drying. The dried microcapsules were then collected for testing.

\section{Characterization of Microcapsules}

\subsection{Scanning Electron Microscopy (SEM)}

To study the shape and size of microcapsules SEM was used (a FEI Quanta 200 FEG-Field Emission Gun with an EDS Detector SiLi (Lithium drifted) with a Super Ultra-Thin window, FEI Company, Hillsboro, OR, USA). The sputter coater used was a Quorum Q150RS (FEI Company, Hillsboro, OR, USA), and it is designed to give an appropriate thin, slight metal coating proper for SEM observation, using $\mathrm{Pt}$ as a target. The coating thickness and uniformity of the sample depends on different factors: distance between sample and target, topography of the sample, and affinity of the material with the metal coating.

\subsection{Differential Scanning Calorimetry (DSC)}

Phase change properties of the fabricated PCM microcapsules and the pure PCM (such as melting and solidification temperatures and their phase change enthalpies) were determined using a SHIMADZU DSC-60 differential scanning calorimeter (Shimadzu Company, Kyoto, Japan). The measurements were performed by varying the temperature between $-15^{\circ} \mathrm{C}$ and $40{ }^{\circ} \mathrm{C}$ with heating and cooling rate of $3^{\circ} \mathrm{C} \cdot \mathrm{min}^{-1}$. Each sample was analyzed for three times and the average was taken. Consequently, the percentage PCM encapsulated can be determined using DSC results and the following Equation (1) [62,63]. The mass content obtained by DSC measurements does not provide accurate measure of the core mass content. Equation (1), which was used to estimate the mass content from DSC measurements, does not take in account the sensible heat of coating materials. The TGA method provides more accurate measure of the core material mass content than DSC. In our previous 
publication [63] the core material mass content of sample M-2 obtained by TGA is $77.5 \mathrm{wt} \%$, which is less than the one obtained by DSC.

$$
\% \mathrm{PCM} \text { in microcapsules by mass }=\Delta \mathrm{H}_{\text {microcapsules }} / \Delta \mathrm{H}_{\text {Pure } \mathrm{PCM}} \times 100 \%
$$

where $\Delta H_{\text {microcapsules }}\left(\mathrm{J} \cdot \mathrm{g}^{-1}\right)$ is the latent heat of the microcapsule containing PCM; and $\Delta H_{\text {purePCM }}$ $\left(\mathrm{J} \cdot \mathrm{g}^{-1}\right)$ is the latent heat of pure PCM (before encapsulation). In Equation (1), it is assumed that the latent heat of the microcapsule without PCM is zero, which is true if phase change does not occur in the shell does.

\subsection{Nano-Indentation Technique}

To characterize the mechanical properties of M-2 and commercial Micronal ${ }^{\circledR}$ DS 5008 X samples, a nano-indentation technique was used. Nano-indentation is identified as an appropriate technique to test the strength of individual microcapsules [64]. MTS Nano Indenter XP (MTS Company, Eden Prairie, MN, USA) was the instrument used. Aluminium stubs of $20 \mathrm{~mm}$ height and $30 \mathrm{~mm}$ diameter were needed to stick the samples at the top to characterize them using a red glue to stick the samples as shown in Figure 1. The instrument parameters were set the same for the two studied samples for a more accurate comparison.
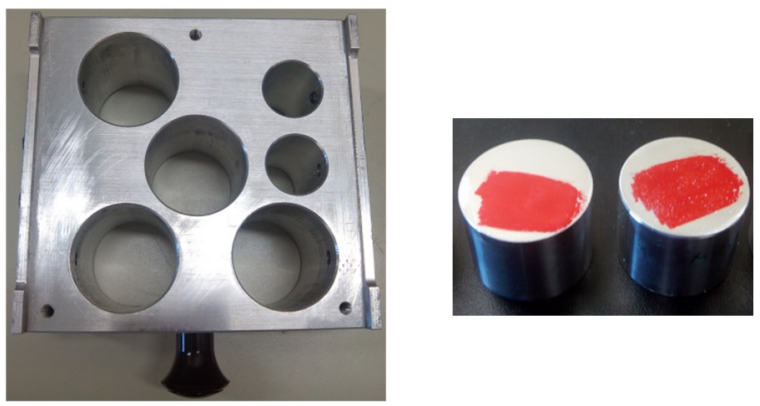

Figure 1. Holder and aluminum stubs with the sample over the red glue.

There are some required inputs to set before starting the experiments: strain rate target of $0.05 \mathrm{~s}^{-1}$, allowable drift rate of $0.05 \mathrm{~nm} \cdot \mathrm{s}^{-1}$, a Poissons' ratio of 0.18 for the tip indenter $[65,66]$ a peak hold time of $10 \mathrm{~s}$, a surface speed of $10 \mathrm{~nm} \cdot \mathrm{s}^{-1}, 25 \%$ of surface approach sensitivity, $90 \%$ to unload, an approach distance to store of $1000 \mathrm{~nm}$, a surface approach distance of $1000 \mathrm{~nm}$, and finally, a depth limit of $5000 \mathrm{~nm}$.

To determine the elastic modulus $(E)$ of the studied samples, a Berkovich tip TB-13288 (Micro Star Technologies, Huntsville, TX, USA) was used. The use of nano-indentation for the characterization of mechanical properties of materials has been extensively studied by several authors. Oliver and Pharr developed extensively the methodology for characterizing ceramic materials [66,67]. They described the typical load vs. displacement curve, where increasing the load $(P)$ increases the displacement (h) until reaching a maximum load $\left(P_{\max }\right)$ and a maximum displacement $\left(h_{\max }\right)$. Following that, the indenter is removed out of the material (unloading section), the load will be zero, and the final displacement $\left(h_{f}\right)$ will be measured. After that, the $E$ value for each sample can be calculated. Hochstetter et al. [68] presented results for glassy polymers and Giro-Paloma et al. [69] compared both methodologies using continuous stiffness measurement (CSM) by applying a small oscillation to the quasi-static component of loading using different thermoplastics suitable as containers for PCM. They concluded that Loubet's method produce lower values of $H$ and $E$ because it uses a dynamic approach for stiffness measurements and the contact depth is larger due to the contribution of the apparent tip effect. In the light of these findings, it was concluded that Loubet's method should be used only with polymeric materials having a low viscous character $\left(T_{g}>T_{\text {measurement }}\right)$. Additionally, in depth-sensing 
indentation (DSI), which is the mode used in this paper, load is applied as a function of penetration depth during the loading and unloading cycle, as described by Fischer-Cripps [70]:

- Hardness $(H)$ is defined as the maximum indentation load divided by the cross-sectional area of the indenter specified at the maximum indentation depth $\left(A\left(h_{m}\right)\right)$.

- Load $\left(P_{m}\right)$ at maximum displacement $(\mathrm{mN})$ : It is the load recorded at the maximum load, which occurs when sample fails.

- Elastic modulus ( $E$ ) is evaluated following Equations (2) and (3) from the nano-indentation test using the maximum indentation load $\left(P_{m}\right)$ and the depth sensing indentation. Hardness $(H)$, elastic work $\left(W_{e}\right)$, and total work $(W)$ can be calculated by integrating the areas under the indentation unloading. $W_{e}$ and $W$ are the elastic work and total work, which are equal to the areas under the unloading and loading curves, respectively which is correlated with $E$ and $H$ through the function $\psi$ described in [71]. $W_{e} / W$ value is independent of the degree of work-hardening behavior [66].

$$
\begin{gathered}
H=P_{m} / A\left(h_{m}\right) \\
E=H / \psi\left(\frac{W_{e}}{W}\right)
\end{gathered}
$$

- Displacement $\left(h_{m}\right)$ at maximum load $(\mathrm{nm})$ is a measure of the extent the tip penetrates into the material.

\subsection{Emission of Volatile Organic Compounds (VOC's)}

A GC-17A Gas chromatograph Shimadzu (Shimadzu Corporation, Kyoto, Japan) coupled to GCMS-QP5000 Gas chromatograph/Mass Spectrometer Shimadzu (Shimadzu Corporation, Kyoto, Japan) was used to characterize the VOC's emissions from each sample. A calibration was performed for each pure compound: $\mathrm{C}_{14} \mathrm{H}_{30}, \mathrm{C}_{15} \mathrm{H}_{32}, \mathrm{C}_{16} \mathrm{H}_{34}, \mathrm{C}_{17} \mathrm{H}_{36}, \mathrm{C}_{18} \mathrm{H}_{38}, \mathrm{C}_{20} \mathrm{H}_{42}, \mathrm{C}_{22} \mathrm{H}_{46}$, and $\mathrm{C}_{24} \mathrm{H}_{50}$, at different temperatures: $25^{\circ} \mathrm{C}, 35^{\circ} \mathrm{C}, 45^{\circ} \mathrm{C}, 55^{\circ} \mathrm{C}$, and $65^{\circ} \mathrm{C}$. A total of 40 experiments for calibration were executed. When the calibration was completed, the same procedure was performed for the two studied samples: M-2 and Micronal ${ }^{\circledR}$ DS 5008 X.

Each sample was independently located inside a crystal vial HS of $50 \mathrm{~mL}$ capacity. The vials were submerged during $30 \mathrm{~min}$ in a water bath until reaching the required temperature. Later on, a fibber solid-phase microextraction (SPME) holder with lot number P268618D 57330-U, provided by Supelco (Sigma-Aldrich Corporation, St. Louis, MO, USA), was punctured on the top of the silicone cap. Following that, $10 \mathrm{~min}$ desorption was applied. The temperature inside the device was $60^{\circ} \mathrm{C}$ during $2 \mathrm{~min}$. After that, a ramp of $15^{\circ} \mathrm{C} \cdot \mathrm{min}^{-1}$ was programmed.

A HP-5MS (1553434H) (Agilent Technologies, Santa Clara, CA, USA) was the column used. Its thickness, length and diameter were $0.5 \mu \mathrm{m}, 30 \mathrm{~m}$, and $0.32 \mathrm{~cm}$, respectively. Additionally, the injection and interface temperature were $200{ }^{\circ} \mathrm{C}$ and $280^{\circ} \mathrm{C}$, respectively inside the gas chromatographer. There were more parameters to take into account, such as inlet pressure: $1 \mathrm{kPa}$, flow: $1.1 \mathrm{~mL} \cdot \mathrm{min}^{-1}$, lineal velocity: $38.7 \mathrm{~cm} \cdot \mathrm{s}^{-1}$, split ratio between peaks of 20, and finally total flow for the He gas of $23.1 \mathrm{~mL} \cdot \mathrm{min}^{-1}$. On the other hand, the mass spectrometer $\mathrm{m} / \mathrm{z}$ values are from 35 to 350 . Moreover, the solvent cut time was $0.5 \mathrm{~min}$.

\section{Results and Discussion}

\subsection{Characterization of MPCM Shape, Size, and Morphology}

SEM images for the two studied samples are shown in Figure 2. M-2 microcapsules morphology appears to be compact and with smooth surface as shown in Figure 2a. Furthermore, their size is around $6 \mu \mathrm{m}$ and has a spherical shape. On the other hand, commercial Micronal ${ }^{\circledR}$ DS $5008 \mathrm{X}$ looks made of a big sphere (around $150 \mu \mathrm{m}$ ) composed of hundreds of other small microcapsules (the ones which contain the PCM) with $6 \mu \mathrm{m}$ in size, approximately as shown in Figure 2b. As Figure 2 shows, 
the $6 \mu \mathrm{m}$ microcapsules of Micronal ${ }^{\circledR}$ DS 5008 X samples are deformed, which is probably due to the process of agglomerating of these microcapsules to form larger particle of $150 \mu \mathrm{m}$, which probably has been made for ease of handling. Accelerated thermal cycling experiments of PCM microcapsules (M-2 containing RT-58 sample) were performed in a controlled heating/cooling water bath at temperatures cycling between 2 and $40{ }^{\circ} \mathrm{C}$ in our previous publication [63]. The results showed that slight changes in phase transition temperatures of the PCM microcapsules (M-2 containing RT58 sample) after 2000 cycles. The latent heat of M-2 sample (based on DSC measurements) showed only a minor change of $2 \%$ after 2000 cycles. Furthermore, SEM images showed that the capsule shape remained spherical and no shell cracks were observed at the end of 2000 cycles.

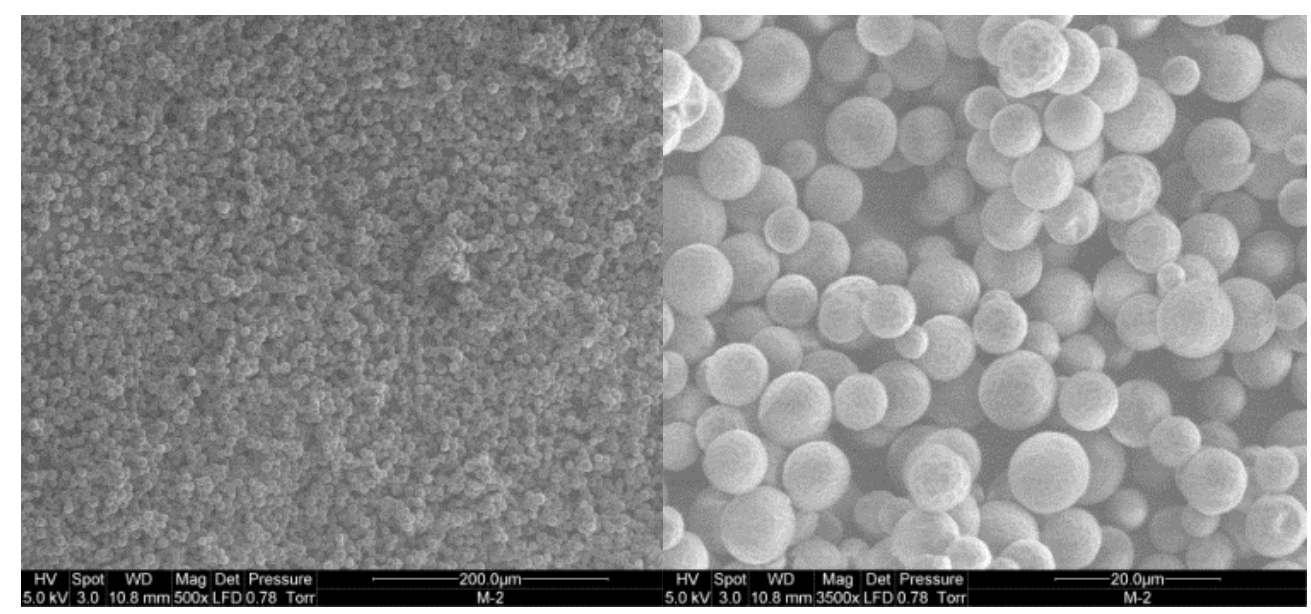

(a)

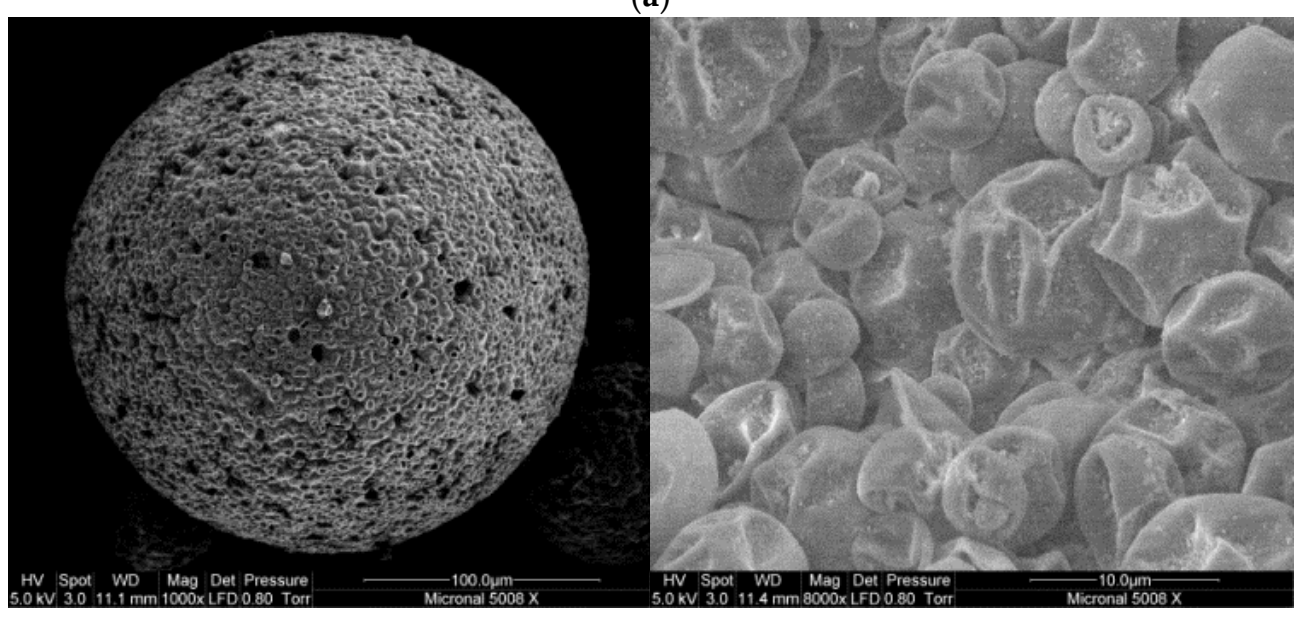

(b)

Figure 2. SEM images for the studied samples: (a) M-2 (magnification: $\times 500$ left and $\times 3500$ right); (b) Micronal ${ }^{\circledR}$ DS 5008 X (magnification: $\times 1000$ left and $\times 8000$ right).

\subsection{Thermophysical Properties of MPCM}

Thermal properties of M-2 and Micronal ${ }^{\circledR}$ DS 5008 X in terms of phase change enthalpies and phase change temperatures were investigated using DSC as shown in Figure 3. Based on DSC measurements, the \% mass of the PCM for M-2 sample is $81.7 \mathrm{wt} \%$ and for Micronal ${ }^{\circledR}$ DS $5008 \mathrm{X}$ is $78.1 \mathrm{wt} \%$. The DSC results show that the thermal energy storage capacity of the M-2 is $113.8 \mathrm{~J} \cdot \mathrm{g}^{-1}$ which corresponds to $85 \mathrm{wt} \%$ of RT-21 encapsulation. The melting temperature of the RT-21 in M-2 microcapsules is similar to that of the bulk RT-21. In contrast, the solidification temperature of the PCM microcapsules was about $14{ }^{\circ} \mathrm{C}$ lower than that of the bulk RT-21 (super-cooling phenomena) as previously reported [72] (see Table 1). The supercooling of PCM in microcapsules has also been 
reported by Qiu et al. [73]. The increase of the degree of super-cooling of RT-21 microcapsules could be attributed either to the decrease in the amount of RT-21 nuclei inside each microcapsule compared to the bulk RT-21 [74] or due to formation of vacuum pockets space inside the microcapsules [75]. To reduce the supercooling of PCM microcapsules, additives were mixed with the PCM prior encapsulation to act as a nucleating agent. These nucleating agents are usually materials with a similar crystal structure as the solid PCM which allow nucleation at their surface but have a higher melting temperature. Figure 4 shows the DSC curve for the microcapsules containing nucleating agent. Commercial RT-58 (paraffin) with peak melting temperatures of $58{ }^{\circ} \mathrm{C}$ was used as nucleating agent. The degree of supercooling has been reduced dramatically as reported in Table 1 and shown in Figure 4.

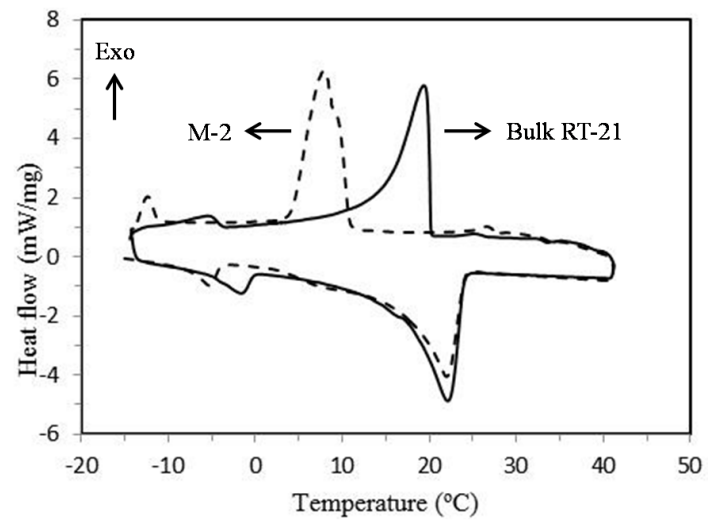

(a)

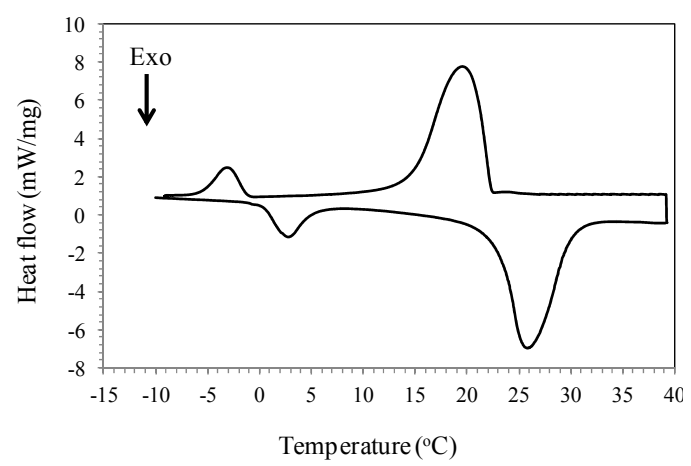

(b)

Figure 3. DSC results for: (a) M-2; and (b) Micronal ${ }^{\circledR}$ DS 5008 X.

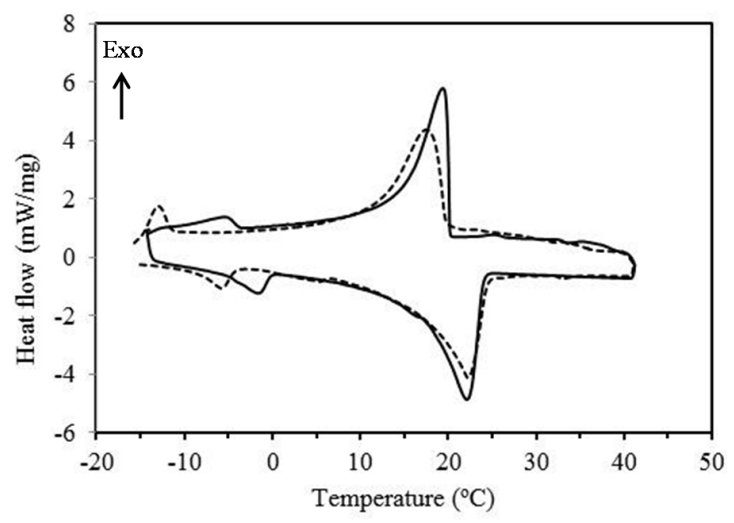

Figure 4. DSC curves of the bulk RT-21 (solid line) and M-2 microcapsules containing nucleating agent, RT-58 (dotted line).

Table 1. Thermophysical properties of fabricated M-2 and commercial Micronal ${ }^{\circledR}$ DS 5008 X.

\begin{tabular}{cccccc}
\hline Status & $\begin{array}{c}\text { Transition Temperatures and } \\
\text { Heat of Fusion }\end{array}$ & M-2 & RT-21 & $\begin{array}{c}\text { Micronal }^{\circledR} \text { DS } \\
\mathbf{5 0 0 8 ~ X}\end{array}$ & $\begin{array}{c}\text { M-2 Containing } \\
\text { RT-58 }\end{array}$ \\
\hline \multirow{4}{*}{ Heating } & $\mathrm{T}_{\text {onset }}\left({ }^{\circ} \mathrm{C}\right)$ & 16.7 & 16.5 & 22.1 & 16.1 \\
& $\mathrm{~T}_{\text {peak }}\left({ }^{\circ} \mathrm{C}\right)$ & 22.0 & 22.1 & 20.3 & 22.3 \\
& $\mathrm{~T}_{\text {endset }}\left({ }^{\circ} \mathrm{C}\right)$ & 24.0 & 23.9 & 26.3 & 24.3 \\
& $\Delta \mathrm{H}\left(\mathrm{J} \cdot \mathrm{g}^{-1}\right)$ & 113.9 & 132.0 & 99.9 & 110.4 \\
\hline \multirow{4}{*}{ Cooling } & $\mathrm{T}_{\text {onset }}\left({ }^{\circ} \mathrm{C}\right)$ & 10.9 & 20.2 & 22.5 & 19.8 \\
& $\mathrm{~T}_{\text {peak }}\left({ }^{\circ} \mathrm{C}\right)$ & 7.9 & 19.4 & 24.2 & 17.5 \\
& $\mathrm{~T}_{\text {endset }}\left({ }^{\circ} \mathrm{C}\right)$ & 4.2 & 14.5 & 17.5 & 11.4 \\
& $\Delta \mathrm{H}\left(\mathrm{J} \cdot \mathrm{g}^{-1}\right)$ & 111.9 & 132.5 & 103.5 & 108.3 \\
\hline
\end{tabular}




\subsection{Mechanical Properties of MPCM}

Results of nano-indentation technique by DSI for the two samples were summarized in Table 2. Ten tests were performed for each sample, but some results were discarded because of the dispersion attributed to indentations in the edge of the microcapsules. For this reason, six results were finally selected. From these measurements the mean value and standard deviation of the elastic modulus $(E)$ were calculated for each sample. These results show that M-2 microcapsules are stiffer than Micronal ${ }^{\circledR}$ DS $5008 \mathrm{X}$ ones.

Table 2. Elastic modulus results of M-2 and Micronal ${ }^{\circledR}$ DS 5008 X.

\begin{tabular}{ccc}
\hline Mechanical Property & M-2 & Micronal $^{\circledR}$ DS 5008 X \\
\hline & 1.89 & 0.15 \\
$E(\mathrm{GPa})$ & 1.04 & 0.19 \\
& 1.16 & 0.17 \\
& 1.68 & 0.24 \\
& 1.38 & 0.22 \\
Mean & 1.9 & 0.28 \\
\hline Standard Deviation & 1.51 & 0.21 \\
\hline
\end{tabular}

Figure 5 is a representation of the $P$ - $h$ curves for the M-2 and Micronal ${ }^{\circledR}$ respectively. The measured typical drift behavior can be observed on the plateau at the end of the unloaded curve. It can be concluded that the mechanical response for M-2 is better than Micronal ${ }^{\circledR}$ DS 5008 X as M-2 microcapsules are more rigid and show higher strength. This fact can be attributed to various factors such as the differences in the encapsulation ratio between samples, shell thickness, type of polymers, as well as degree of polymerization of the shells. These results should be compared when mixing these MPCM in a real system, such us mixing them with a cement-based matrix or gypsum.

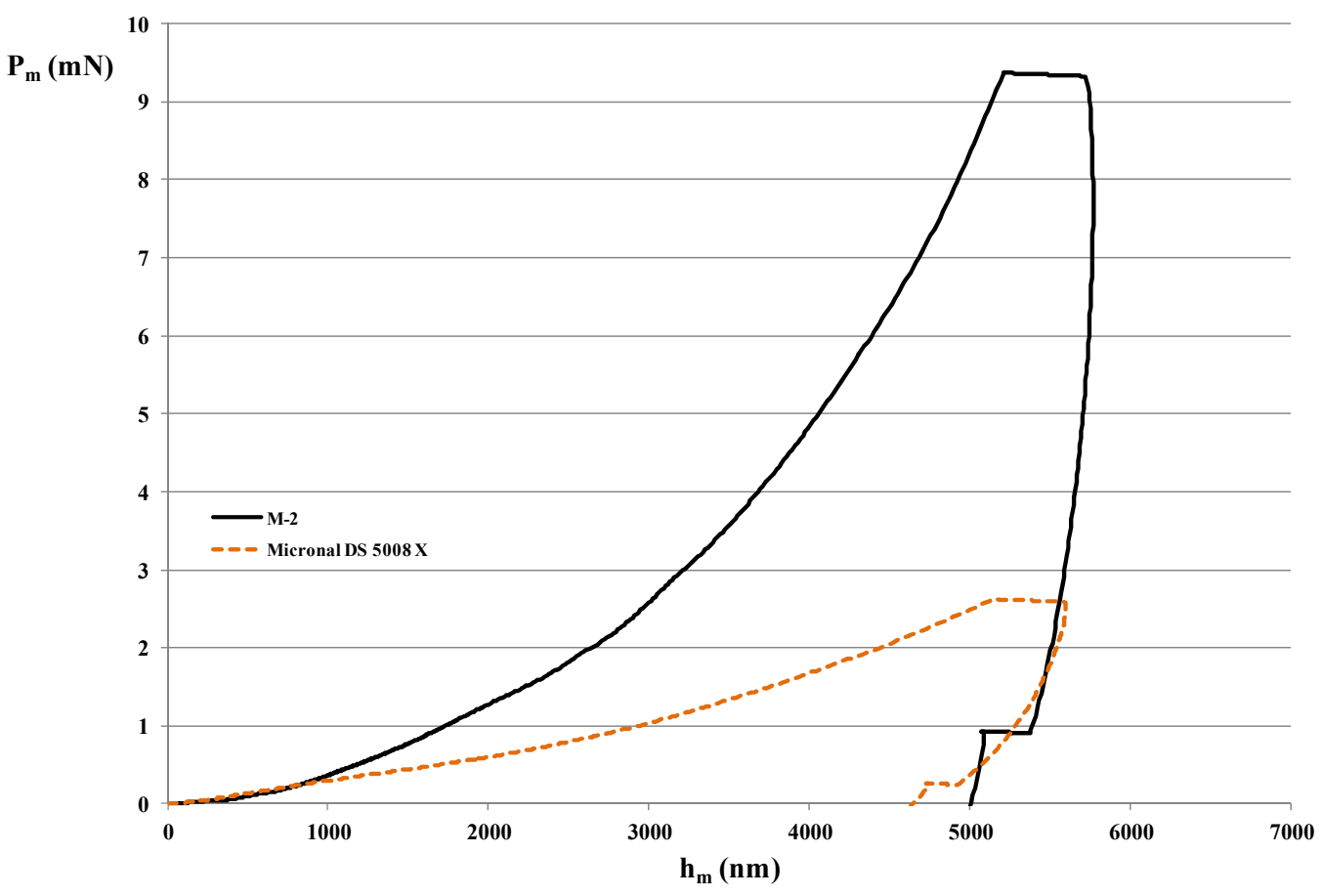

Figure 5. $h_{m}$ vs. $P_{m}$, comparison of the samples under study. 


\subsection{Characterization of Volatile Organic Compounds (VOCs)}

The results of VOCs' short-term release from the two studied samples are shown in Table 3. Each peak in the GC spectra was given at a certain retention time ( $t_{r}$, in minutes), which was related to a specific compound, according to the calibration conducted in this work.

Table 3. VOC emission results for M-2 and Micronal ${ }^{\circledR}$ DS 5008 X samples.

\begin{tabular}{ccccc}
\hline \multirow{2}{*}{ Temperature } & \multicolumn{2}{c}{ M-2 } & \multicolumn{2}{c}{ Micronal ${ }^{\circledR}$ DS 5008 X } \\
\cline { 2 - 5 } & $\mathbf{t}_{\mathbf{r}}$ (min) & Compound & $\mathbf{t}_{\mathbf{r}}$ (min) & Compound \\
\hline $25^{\circ} \mathrm{C}$ & \multicolumn{2}{c}{ No signal } & \multicolumn{2}{c}{ No signal } \\
\hline $35^{\circ} \mathrm{C}$ & \multicolumn{2}{c}{ No signal } & \multicolumn{2}{c}{ No signal } \\
\hline \multirow{2}{*}{$45^{\circ} \mathrm{C}$} & \multicolumn{2}{c}{ No signal } & 11.88 & $\mathrm{C}_{17} \mathrm{H}_{36}$ \\
& \multicolumn{2}{c}{ No signal } & 11.88 & $\mathrm{C}_{18} \mathrm{H}_{38}$ \\
\hline \multirow{2}{*}{$55^{\circ} \mathrm{C}$} & \multicolumn{2}{c}{12.65} & $\mathrm{C}_{17} \mathrm{H}_{36}$ \\
& 9.25 & $\mathrm{C}_{14} \mathrm{H}_{38} \mathrm{H}_{30}$ & - & - \\
\hline \multirow{2}{*}{$65^{\circ} \mathrm{C}$} & 10.18 & $\mathrm{C}_{15} \mathrm{H}_{32}$ & - & - \\
& 11.06 & $\mathrm{C}_{16} \mathrm{H}_{34}$ & - & - \\
& 11.91 & $\mathrm{C}_{17} \mathrm{H}_{36}$ & 11.85 & $\mathrm{C}_{17} \mathrm{H}_{36}$ \\
& 12.68 & $\mathrm{C}_{18} \mathrm{H}_{38}$ & 12.63 & $\mathrm{C}_{18} \mathrm{H}_{38}$ \\
\hline
\end{tabular}

It may be observed from the results that some emissions from Micronal ${ }^{\circledR}$ DS 5008 X sample after 10 min exposure at $45^{\circ} \mathrm{C}$ and $55^{\circ} \mathrm{C}$ were detected while nothing was detected from M-2 microcapsules. After $10 \mathrm{~min}$ exposure at $65^{\circ} \mathrm{C}$, both samples release volatile compounds, but with much lower level for M-2 microcapsules in comparison with Micronal ${ }^{\circledR}$ DS 5008 X. This is confirmed by the high intensity peak for Micronal ${ }^{\circledR}$ DS 5008 X comparing both figures in Figure 6. The multiple peaks for M-2 show the presence of tetradecane, pentacosane, hexadecane, heptadecane, and octadecane in the original PCM, which is RT-21, while only two peaks were observed for the PCM used in Micronal ${ }^{\circledR}$ DS $5008 \mathrm{X}$, indicating that the latter is of higher purity. Although the results for the short-term emissions are relevant, the long term time-dependent release should be studied in a system after prolonged exhibition to evaluate the VOCs' emissions in real conditions.

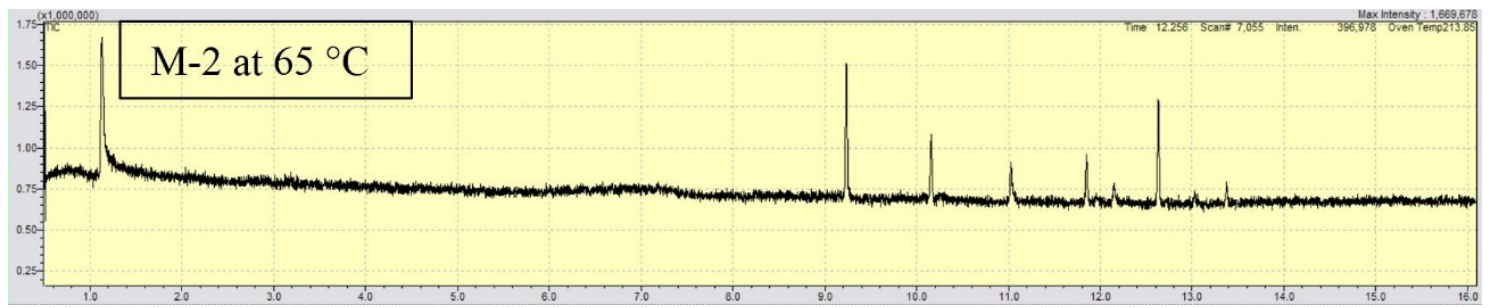

(a)

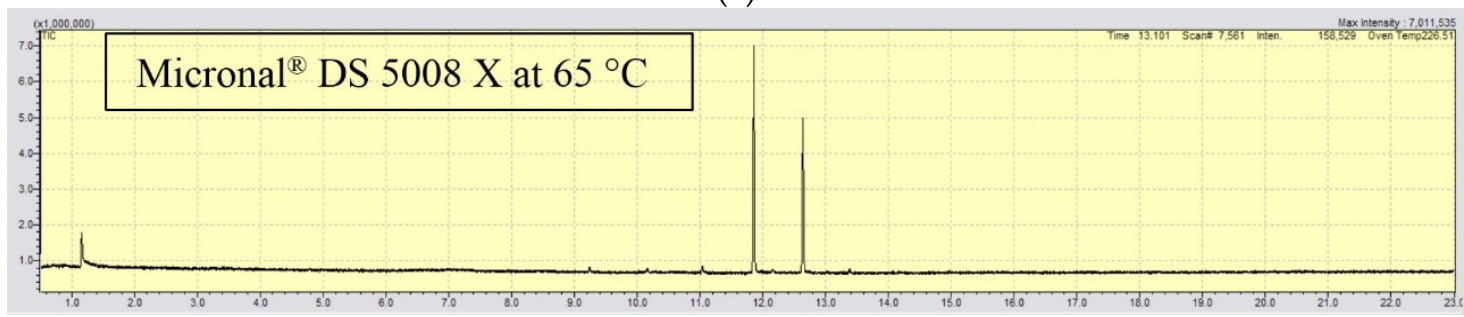

(b)

Figure 6. Revealed peaks for the GC/MS analysis for: (a) M-2 and; (b) Micronal ${ }^{\circledR}$ DS 5008 X samples at $65^{\circ} \mathrm{C}$. 


\section{Conclusions}

A comparison for the characteristic of two MPCM samples was conducted: one sample was Micronal ${ }^{\circledR}$ DS5008 X while the other was made in our laboratory (M-2). The shell material for both samples is similar in terms of chemical composition. Following SEM observation, it can be concluded that the two samples have similar shape and diameter of about $6 \mu \mathrm{m}$, but they have different morphology since Micronal ${ }^{\circledR}$ DS 5008 X capsules were produced as aggregates of many microcapsules. Regarding the thermophysical properties for both samples, their thermal energy storage (TES) capacity were $111.7 \mathrm{~J} \cdot \mathrm{g}^{-1}$ and $99.3 \mathrm{~J} \cdot \mathrm{g}^{-1}$ for M-2 and Micronal ${ }^{\circledR}$ DS $5008 \mathrm{X}$, respectively. The mechanical testing was performed by measuring elastic modulus $(E)$, load at displacement $\left(P_{m}\right)$, and displacement at maximum load $\left(h_{m}\right)$ using nano-indentation technique. Different results were obtained for both samples, showing that evaluating the isolated M-2 sample has better mechanical resistance and stiffness. Finally, a comparative evaluation of the VOC's release at $25^{\circ} \mathrm{C}, 35^{\circ} \mathrm{C}, 45^{\circ} \mathrm{C}$, $55^{\circ} \mathrm{C}$, and $65^{\circ} \mathrm{C}$ was performed in order to study the volatiles emission from these microcapsules. M-2 microcapsules show better stability with less short-term emission of VOC's than Micronal ${ }^{\circledR}$ DS $5008 \mathrm{X}$.

Acknowledgments: Authors acknowledge the support received from the European Union's Seventh Framework Programme (FP7/2007-2013) under grant agreement No: PIRSES-GA-2013-610692 (INNOSTORAGE). Also, we would like to acknowledge the support we have received form Qatar Foundation in supporting the project No: NPRP 5-093-2-034.

Author Contributions: Mohammed M. Farid and Ana Inés Fernández conceived and designed the experiments; Jessica Giro-Paloma and Refat Al-Shannaq performed the experiments; all the authors analyzed the data; Mohammed M. Farid contributed reagents/materials/analysis tools; Jessica Giro-Paloma and Refat Al-Shannaq wrote the paper.

Conflicts of Interest: The authors declare no conflict of interest. The founding sponsors had no role in the design of the study; in the collection, analyses, or interpretation of data; in the writing of the manuscript, and in the decision to publish the results.

\section{References}

1. Zhou, D.; Zhao, C.Y.; Tian, Y. Review on thermal energy storage with phase change materials (PCMs) in building applications. Appl. Energy 2012, 92, 593-605. [CrossRef]

2. Sharma, A.; Tyagi, V.V.; Chen, C.R.; Buddhi, D. Review on thermal energy storage with phase change materials and applications. Renew. Sustain. Energy Rev. 2009, 13, 318-345. [CrossRef]

3. Kuznik, F.; David, D.; Johannes, K.; Roux, J.-J. A review on phase change materials integrated in building walls. Renew. Sustain. Energy Rev. 2011, 15, 379-391. [CrossRef]

4. Farid, M.M.; Khudhair, A.M.; Razack, S.A.K.; Al-Hallaj, S. A review on phase change energy storage: Materials and applications. Energy Convers. Manag. 2004, 45, 1597-1615. [CrossRef]

5. Cabeza, L.F.; Castell, A.; Barreneche, C.; de Gracia, A.; Fernández, A.I. Materials used as PCM in thermal energy storage in buildings: A review. Renew. Sustain. Energy Rev. 2011, 15, 1675-1695. [CrossRef]

6. Soares, N.; Costa, J.J.; Gaspar, A.R.; Santos, P. Review of passive PCM latent heat thermal energy storage systems towards buildings' energy efficiency. Energy Build. 2013, 59, 82-103. [CrossRef]

7. Griffiths, P.W.; Eames, P.C. Performance of chilled ceiling panels using phase change material slurries as the heat transport medium. Appl. Therm. Eng. 2007, 27, 1756-1760. [CrossRef]

8. Huang, L.; Petermann, M.; Doetsch, C. Evaluation of paraffin/water emulsion as a phase change slurry for cooling applications. Energy 2009, 34, 1145-1155. [CrossRef]

9. Youssef, Z.; Delahaye, A.; Huang, L.; Trinquet, F.; Fournaison, L.; Pollerberg, C.; Doetsch, C. State of the art on phase change material slurries. Energy Convers. Manag. 2013, 65, 120-132. [CrossRef]

10. Pendyala, S. Macroencapsulation of Phase Change Materials for Thermal Energy Storage. Master Thesis, University of South Florida, Tampa, FL, USA, 22 June 2012.

11. Calvet, N.; Py, X.; Olivès, R.; Bédécarrats, J.-P.; Dumas, J.-P.; Jay, F. Enhanced performances of macro-encapsulated phase change materials (PCMs) by intensification of the internal effective thermal conductivity. Energy 2013, 55, 956-964. [CrossRef] 
12. Zhao, C.Y.; Zhang, G.H. Review on microencapsulated phase change materials (MEPCMs): Fabrication, characterization and applications. Renew. Sustain. Energy Rev. 2011, 15, 3813-3832. [CrossRef]

13. Giro-Paloma, J.; Oncins, G.; Barreneche, C.; Martínez, M.; Fernández, A.I.; Cabeza, L.F. Physico-chemical and mechanical properties of microencapsulated phase change material. Appl. Energy 2013, 109, 441-448. [CrossRef]

14. Al Shannaq, R.; Farid, M.M. Microencapsulation of phase change materials (PCMs) for thermal energy storage systems. In Advances in Thermal Energy Storage Systems; Cabeza, L.F., Ed.; Elsevier: Amsterdam, The Netherlands, 2015; pp. 247-284.

15. Alvarado, J.L.; Marsh, C.; Sohn, C.; Phetteplace, G.; Newell, T. Thermal performance of microencapsulated phase change material slurry in turbulent flow under constant heat flux. Int. J. Heat Mass Transf. 2007, 50, 1938-1952. [CrossRef]

16. Diaconu, B.M.; Varga, S.; Oliveira, A.C. Experimental study of natural convection heat transfer in a microencapsulated phase change material slurry. Energy 2010, 35, 2688-2693. [CrossRef]

17. Zhang, P.; Ma, Z.W.; Wang, R.Z. An overview of phase change material slurries: MPCS and CHS. Renew. Sustain. Energy Rev. 2010, 14, 598-614. [CrossRef]

18. Zhang, P.; Ma, Z.W. An overview of fundamental studies and applications of phase change material slurries to secondary loop refrigeration and air conditioning systems. Renew. Sustain. Energy Rev. 2012, 16, 5021-5058. [CrossRef]

19. Medrano, M.; Yilmaz, M.O.; Nogués, M.; Martorell, I.; Roca, J.; Cabeza, L.F. Experimental evaluation of commercial heat exchangers for use as PCM thermal storage systems. Appl. Energy 2009, 86, 2047-2055. [CrossRef]

20. Su, J.-F.; Wang, L.-X.; Ren, L. Preparation and characterization of double-MF shell microPCMs used in building materials. J. Appl. Polym. Sci. 2005, 97, 1755-1762. [CrossRef]

21. Khudhair, A.M.; Farid, M.M. A review on energy conservation in building applications with thermal storage by latent heat using phase change materials. Energy Convers. Manag. 2004, 45, 263-275. [CrossRef]

22. Alawadhi, E.M. Thermal analysis of a building brick containing phase change material. Energy Build. 2008, 40, 351-357. [CrossRef]

23. Sarı, A.; Alkan, C.; Karaipekli, A.; Uzun, O. Microencapsulated n-octacosane as phase change material for thermal energy storage. Sol. Energy 2009, 83, 1757-1763. [CrossRef]

24. Cabeza, L.F.; Castellón, C.; Nogués, M.; Medrano, M.; Leppers, R.; Zubillaga, O. Use of microencapsulated PCM in concrete walls for energy savings. Energy Build. 2007, 39, 113-119. [CrossRef]

25. Castellón, C.; Medrano, M.; Roca, J.; Cabeza, L.F.; Navarro, M.E.; Fernández, A.I.; Lázaro, A.; Zalba, B. Effect of microencapsulated phase change material in sandwich panels. Renew. Energy 2010, 35, 2370-2374. [CrossRef]

26. Toppi, T.; Mazzarella, L. Gypsum based composite materials with micro-encapsulated PCM: Experimental correlations for thermal properties estimation on the basis of the composition. Energy Build. 2013, 57, 227-236. [CrossRef]

27. Entrop, A.G.; Brouwers, H.J.H.; Reinders, A.H.M.E. Experimental research on the use of micro-encapsulated Phase Change Materials to store solar energy in concrete floors and to save energy in Dutch houses. Sol. Energy 2011, 85, 1007-1020. [CrossRef]

28. Tyagi, V.V.; Kaushik, S.C.; Tyagi, S.K.; Akiyama, T. Development of phase change materials based microencapsulated technology for buildings: A review. Renew. Sustain. Energy Rev. 2011, 15, 1373-1391. [CrossRef]

29. Zalba, B.; Marín, J.M.; Cabeza, L.F.; Mehling, H. Review on thermal energy storage with phase change: Materials, heat transfer analysis and applications. Appl. Therm. Eng. 2003, 23, 251-283. [CrossRef]

30. Alkan, C.; Sari, A. Fatty acid/poly(methyl methacrylate) (PMMA) blends as form-stable phase change materials for latent heat thermal energy storage. Sol. Energy 2008, 82, 118-124. [CrossRef]

31. Zhang, H.; Xu, Q.; Zhao, Z.; Zhang, J.; Sun, Y.; Sun, L.; Xu, F.; Sawada, Y. Preparation and thermal performance of gypsum boards incorporated with microencapsulated phase change materials for thermal regulation. Sol. Energy Mater. Sol. Cells 2012, 102, 93-102. [CrossRef]

32. Borreguero, A.M.; Garrido, I.; Valverde, J.L.; Rodríguez, J.F.; Carmona, M. Development of smart gypsum composites by incorporating thermoregulating microcapsules. Energy Build. 2014, 76, 631-639. [CrossRef] 
33. Karkri, M.; Lachheb, M.; Albouchi, F.; Nasrallah, S.B.; Krupa, I. Thermal properties of smart microencapsulated paraffin/plaster composites for the thermal regulation of buildings. Energy Build. 2015, 88, 183-192. [CrossRef]

34. Eddhahak-Ouni, A.; Drissi, S.; Colin, J.; Neji, J.; Care, S. Experimental and multi-scale analysis of the thermal properties of Portland cement concretes embedded with microencapsulated Phase Change Materials (PCMs). Appl. Therm. Eng. 2014, 64, 32-39. [CrossRef]

35. Schlink, U.; Rehwagen, M.; Damm, M.; Richter, M.; Borte, M.; Herbarth, O. Seasonal cycle of indoor-VOCs: Comparison of apartments and cities. Atmos. Environ. 2004, 38, 1181-1190. [CrossRef]

36. Ayoko, G.A. Volatile organic compounds in indoor environments. In The Handbook of Environmental Chemistry; Pluschke, P., Ed.; Springer-Verlag: Heidelberg, Germany, 2004; pp. 1-35.

37. Gallego, E.; Roca, X.; Perales, J.F.; Guardino, X. Determining indoor air quality and identifying the origin of odour episodes in indoor environments. J. Environ. Sci. 2009, 21, 333-339. [CrossRef]

38. Missia, D.A.; Demetriou, E.; Michael, N.; Tolis, E.I.; Bartzis, J.G. Indoor exposure from building materials: A field study. Atmos. Environ. 2010, 44, 4388-4395. [CrossRef]

39. Shin, S.H.; Jo, W.K. Volatile organic compound concentrations, emission rates, and source apportionment in newly-built apartments at pre-occupancy stage. Chemosphere 2012, 89, 569-578. [CrossRef] [PubMed]

40. Huang, H.; Haghighat, F. Building materials VOC emissions-A systematic parametric study. Build. Environ. 2003, 38, 995-1005. [CrossRef]

41. Zhang, Y.; Xu, Y. Characteristics and correlations of VOC emissions from building materials. Int. J. Heat Mass Transf. 2003, 46, 4877-4883. [CrossRef]

42. Kim, S.; Choi, Y.-K.; Park, K.-W.; Kim, J.T. Test methods and reduction of organic pollutant compound emissions from wood-based building and furniture materials. Bioresour. Technol. 2010, 101, 6562-6568. [CrossRef] [PubMed]

43. Lee, C.-S.; Haghighat, F.; Ghaly, W. Conjugate mass transfer modeling for VOC source and sink behavior of porous building materials: When to apply it? J. Build. Phys. 2006, 30, 91-111. [CrossRef]

44. Haghighat, F.; Huang, H. Integrated IAQ model for prediction of VOC emissions from building material. Build. Environ. 2003, 38, 1007-1017. [CrossRef]

45. Lee, C.-S.; Haghighat, F.; Ghaly, W.S. A study on VOC source and sink behavior in porous building materials-Analytical model development and assessment. Indoor Air 2005, 15, 183-96. [CrossRef] [PubMed]

46. Kim, S.; Kim, H.-J.; Moon, S.-J. Evaluation of VOC emissions from building finishing materials using a small chamber and VOC analyser. Indoor Built Environ. 2006, 15, 511-523. [CrossRef]

47. Magee, R.J.; Bodalal, A.; Biesenthal, T.A.; Lusztyk, E.; Brouzes, M.; Shaw, C.Y. Prediction of VOC Concentration Profiles in a Newly Constructed House Using Small Chamber Data and an IAQ Simulation Program. In Proceedings of the 9th International Conference on IAQ and Climate, Monterey, CA, USA, 30 June-5 July 2002; pp. 298-303.

48. Jia, C.; Batterman, S.A.; Relyea, G.E. Variability of indoor and outdoor VOC measurements: An analysis using variance components. Environ. Pollut. 2012, 169, 152-159. [CrossRef] [PubMed]

49. Norbäck, D.; Torgén, M.; Edling, C. Volatile organic compounds, respirable dust, and personal factors related to prevalence and incidence of sick building syndrome in primary schools. Br. J. Ind. Med. 1990, 47, 733-741. [CrossRef] [PubMed]

50. Redlich, C.A.; Sparer, J.; Cullen, M.R. Sick-building syndrome. Lancet 1997, 349, 1013-1016. [CrossRef]

51. Apte, M.G.; Daisey, J.M. VOCs and "Sick Building Syndrome": Application of a New Statistical Approach for SBS Research to US EPA BASE Study Data. In Proceedings of the Indoor Air 99, Edinburgh, Scotland, 30 June-5 July 1999; pp. 2-7.

52. Rufford, T.E.; Zhu, J.; Hulicova-Jurcakova, D. Green Carbon Materials: Advances and Applications; Pan Stanford: Boca Raton, FL, USA, 2014; pp. 1-288.

53. Standard Guide for Small-Scale Environmental Chamber Determinations of Organic Emissions from Indoor Material/Products; ASTM Standard D5116-97; ASTM International: West Conshohocken, PA, USA, 1997.

54. Standard Test Method for Determining Formaldehyde Concentrations in Air from Wood Products Using a Small Scale Chamber; ASTM Standard D6007-96; ASTM International: West Conshohocken, PA, USA, 1996.

55. Won, D.; Magee, R.J.; Lusztyk, E.; Nong, G.; Zhu, J.P.; Zhang, J.S.; Reardon, J.T.; Shaw, C.Y. A Comprehensive VOC Emission Database for Commonly-Used Building Materials. In Proceedings of the 7th International Conference of Healthy Buildings, Singapore, 7-11 December 2003; pp. 1-6. 
56. Ouazia, B.; Reardon, J.; Sander, D. Making the Case for Reducing Ventilation Requirements through Selection of Low-Emission Materials. In Proceedings of the 10th International Conference on Indoor Air Quality and Climate, Beijing, China, 4-9 September 2005.

57. Xiong, J.; Zhang, Y.; Huang, S. Characterization of VOC and formaldehyde emission from building materials in static environmental chamber: Model development and application. Indoor Built Environ. 2011, 20, $217-225$. [CrossRef]

58. Knöppel, H.; Schauenburg, H. Screening of household products for the emission of volatile organic compounds. Environ. Int. 1989, 15, 413-418. [CrossRef]

59. Lin, C.-C.; Yu, K.-P.; Zhao, P.; Lee, G. Evaluation of impact factors on VOC emissions and concentrations from wooden flooring based on chamber tests. Build. Environ. 2009, 44, 525-533. [CrossRef]

60. Safari, V.; Barreneche, C.; Castell, A.; Basatni, A.; Navarro, L.; Cabeza, L.; Haghighat, F. Volatile Organic Emission from PCM Building Materials. In Proceedings of the Innostock 2012-The 12th International Conference on Energy Storage, Lleida, Spain, 16-18 May 2012.

61. Sánchez, L.; Sánchez, P.; de Lucas, A.; Carmona, M.; Rodríguez, J.F. Microencapsulation of PCMs with a polystyrene shell. Colloid Polym. Sci. 2007, 285, 1377-1385. [CrossRef]

62. Sánchez-Silva, L.; Rodríguez, J.F.; Romero, A.; Borreguero, A.M.; Carmona, M.; Sánchez, P. Microencapsulation of PCMs with a styrene-methyl methacrylate copolymer shell by suspension-like polymerisation. Chem. Eng. J. 2010, 157, 216-222. [CrossRef]

63. Al-Shannaq, R.; Kurdi, J.; Al-Muhtaseb, S.; Dickinson, M.; Mohammed, F. Supercooling elimination of phase change materials (PCMs) microcapsules. Energy 2015, 87, 654-662. [CrossRef]

64. Rahman, A.; Dickinson, M.E.; Farid, M.M. Microencapsulation of a PCM through membrane emulsification and nanocompression-based determination of microcapsule strength. Mater. Renew. Sustain. Energy 2012, 1. [CrossRef]

65. Troyon, M.; Huang, L. Correction factor for contact area in nanoindentation measurements. J. Mater. Res. 2011, 20, 610-617. [CrossRef]

66. Oliver, W.C.; Pharr, G.M. Measurement of hardness and elastic modulus by instrumented indentation: Advances in understanding and refinements to methodology. J. Mater. Res. 2004, 19, 3-20. [CrossRef]

67. Oliver, W.C.; Pharr, G.M. An improved technique for determining hardness and elastic modulus using load and displacement sensing indentation experiments. J. Mater. Res. 1992, 7, 1564-1580. [CrossRef]

68. Hochstetter, G.; Jimenez, A.; Loubet, J.L. Strain-rate effects on hardness of glassy polymers in the nanoscale range. Comparison between quasi-static and continuous stiffness measurements. J. Macromol. Sci. Part B 2006, 38, 681-692. [CrossRef]

69. Giro-Paloma, J.; Roa, J.J.; Díez-Pascual, A.M.; Rayón, E.; Flores, A.; Martínez, M.; Chimenos, J.M.; Fernández, A.I. Depth-sensing indentation applied to polymers: A comparison between standard methods of analysis in relation to the nature of the materials. Eur. Polym. J. 2013, 49, 4047-4053. [CrossRef]

70. Fischer-Cripps, A.C. Introduction to Contact Mechanics, 2nd ed.; Springer: New York, NY, USA, 2007 ; p. 221.

71. Ma, D. New relationship between Young's modulus and nonideally sharp indentation parameters. J. Mater. Res. 2004, 19, 2144-2151. [CrossRef]

72. Al-Shannaq, R.; Farid, M.; Al-Muhtaseb, S.; Kurdi, J. Emulsion stability and cross-linking of PMMA microcapsules containing phase change materials. Sol. Energy Mater. Sol. Cells 2015, 132, 311-318. [CrossRef]

73. Qiu, X.; Li, W.; Song, G.; Chu, X.; Tang, G. Fabrication and characterization of microencapsulated n-octadecane with different crosslinked methylmethacrylate-based polymer shells. Sol. Energy Mater. Sol. Cells 2012, 98, 283-293. [CrossRef]

74. Zhang, X.; Fan, Y.; Tao, X.; Yick, K. Crystallization and prevention of supercooling of microencapsulated n-alkanes. J. Colloid Interface Sci. 2005, 281, 299-306. [CrossRef] [PubMed]

75. Chaiyasat, P.; Ogino, Y.; Suzuki, T.; Okubo, M. Influence of water domain formed in hexadecane core inside cross-linked capsule particle on thermal properties for heat storage application. Colloid Polym. Sci. 2008, 286, 753-759. [CrossRef]

(C) 2015 by the authors; licensee MDPI, Basel, Switzerland. This article is an open access article distributed under the terms and conditions of the Creative Commons by Attribution (CC-BY) license (http://creativecommons.org/licenses/by/4.0/). 